\title{
The Dimension of Tasawwuf and Aesthetical Concept of the Indang Pariaman Art Form in Minangkabau -- Indonesia
}

\author{
Wilma Sriwulan $\quad{ }^{1}$ Andar Indra Sastra \\ Indonesia Institute of the Arts (ISI) Padangpanjang, West Sumatera, Indonesia
}

\begin{abstract}
This article aims to reveal the dimension of tasawwuf and the aesthetical concept of the performing art indang Pariaman in Minangkabau. The dimension of tasawwuf is an aspect of spirituality that is related to the mystification of the number 7 (seven) - a method of ascending levels (tarqy) to enter into the realm of the Divine Being - "martabat nan tujuh". The aesthetical concept is related to the aesthetical principle involving the number 7 (seven) in the organization of the indang Pariaman art form. This includes using 7 (seven) indang players (anak indang) in each group; holding performances for 14 nights in a row, which is the same as $2 \times 7$; and involving 21 indang groups in a performance, which is the same as 3 x 7. "Martabat nan tujuh" (literally "seven dignities") is a principle of divinity in tasawwuf which states that everything that exists in the universe is an external aspect of a single divine essence, namely God. The goal of tasawwuf is to reach Dzat Al Haqq or the Divine Essence (God) and become one with Him. The seven stages in the method of tasawwuf are the implementation of the knowledge of martabat nan tujuh; the symbol seven in the organization of the performing art indang is related to the concept of aesthetics. The two are in different domains - art is a representation of a social concept. The problem addressed in this article is: the dimension of tassawuf and martabat nan tujuh and the aesthetical form of an indang Pariaman performance. The study is based on qualitative research and relies on the researcher as the main instrument for collecting, arranging, and analyzing data. The results of the study reveal a synchronization between the dimension of tasawwuf which is related to the mystification of the number 7 (seven) and the system of organization of an indang performance in the Pariaman community.
\end{abstract}

Keywords: dimension of tasawwuf, aesthetics, indang Pariaman, Minangkabau

DOI: $10.7176 / \mathrm{ADS} / 78-04$

Publication date: November 30th 2019

\section{INTRODUCTION}

It cannot be denied that the religious life of the Minangkabau community is coloured by existence oftarekatwhich practice the teachings of tasawwuf - one of which is tarekat Syattariyah. Christine Dobbin (1992) describes a tarekat as a religious sect whose members follow a tariqah with mystic connotations. Tariqah means path or way: a special pathway to God followed by the members of a Muslim brotherhood. In English, tasawwufis explained asIslamic mysticism. The main goal of a person who practices tasawwuf teachings, according to Abdul Hakim Hasan in Simuh (1995), is to reach Dzat Al Haqq or the Divine Essence (God) and become one with Him.

Taufik Abdullah (1987) states that tarekat Syattariyah is a religious sect that was founded by an expert in tasawwuf by the name of Abdullah Syatar. In thistarekat, the members perform dhikr (repeatedly reciting the name of Allah) with their eyes closed and prayer beads in their hands to determine the number of times the name of Allah is repeated. From a historical aspect, Van Rongkel in Burhanuddin Daya (1995) states that tarekat Syattariyah first entered Indonesia (Aceh, Sumatera) around the year 1665 under the influence of Abdur Rauf Singkel (d. 1694). Subsequently, Syeikh Burhanuddin, one of his entrusted students, brought thisparticular tarekat to the region of Pariaman in Minangkabau. This is why the Minangkabau communities living along the west coast of West Sumatera, especially in Pariaman, are dominated by followers of tarekat Syattariyah.

Indang is one of the art forms that was originally used a medium for da'wah to help spread Islamic teachings in Minangkabau. Ediwar (1999) states that the art of indang was used by Syeikh Burhanuddin in his mission to develop Islam through da'wah. The material presented was related to the "twenty characteristics" (sifat duapuluh) and told the story of the prophets and the sheikhs. The religious themes were sung while dancing and playing the rapa' $i$, a kind of tambourine or rebana. In its performance, the art of indang is presented by groups of men who sit in rows with their legs touching, each group consisting of 7 (seven) players (anak indang).

Today, the tradition of indang performance in the Pariaman community is no longer the same as during its early years when it was used to introduce and propagate Islam. Nowadays, it is oriented more towards an art performance that is associated with alek nagari ceremonies (village folk festivals). Ediwar (1999) mentions two forms of alek nagari ceremony, namely a large-scale ceremony (alek gadang) and a small-scale ceremony (alek

\footnotetext{
${ }^{1}$ Corresponding author: Andar Indra Sastra, Indonesia Institute of the Arts (ISI) Padangpanjang (Indonesia). Jln Bahder Johan Padangpanjang 27128, West Sumatera
} 
ketek). Alek gadang is an event in which indang is performed by 21 different groups over a period of 14 nights and consists of 7 (seven)performances or 7 (seven) times "naiak indang"[performing - going up onto the stage]. Meanwhile, alek ketek is a smaller performance of indang which according to Asril (2017) is described as 3 (three) times"naiak indang". Three times naiak indang is equal to 6 (six) nights of performances given by 9 indang groups (Asril, interview 2017).

Seven times naiak indang is equivalent to 14 nights of performing; sapanaiak indang (one time performing indang or naiak indang) is the same as two nights of performances, which consist of indang naiak (the initial performance) and indang lambuang (the climax of the performance). Sapanaik indang means a performance ofindangover 2 (two) nights by 3 (three) different indang groups. Asril (2017) states that an event which includes 7 (seven) times naiak indang, consists of 7 (seven) of each kind of indang group (the sapangka or host, alek duo or close guests, and alek satu or distant guests) (Asril, interview 2017). The concept of the numbers 3 (three); 7 (seven) and 2 (two) x 7 (seven) in the system of anindangperformance is connected with the concept of the social life of the Pariaman community. Three, seven, and two times seven are usually associated with ceremonies to commemorate a person's death day. Meanwhile, the concept of $3 \times 7$ is usually used in the world of shamanism. Martabat nan tujuh in the dimension of tasawwuf is related to a method of levels that must be passed through to enter the realm of the Divine Being. The organization of indang which uses the symbol 7 (seven) and multiples there of is in the domain of the performing arts.

The dimension of tasawwuf and the formation of the aesthetical concept in the performance of indang Pariaman is interesting to explore, especially in connection with its use of the symbol or number 7 (seven) and its multiples. The ontological dimension of the phenomenon of tasawwuf is interesting to discuss in connection with the wujudyyah teachings institutionalized by the tarekat Syattariyah group in Minangkabau.The ontological dimension is related to the Sufi principles that are concerned with how the tasawwuf philosophy of wujudyyah becomes the precept for carrying out religious practices. The tasawwuf wujudyyah teachings are based on a religious doctrine which tasawwuf leaders refer to as knowledge of "martabat nan tujuh".

In the proceedings of a seminar, Johari Mat (1999), in answer to two questions posed by Mohd Iqbal which are misleading and should be avoided - states that ... in tasawwuf philosophy, we are allowed to become God, because in the book of 'Saidussadiqin', after the chapters of Tawhid, man is permitted to become Insanul Kamil. The meaning of Insanul Kamil (a person who has reached perfection) is al-insanul-illahi (a man of God). From one point of view, he is seen as human, from another point of view, as God. This is the meaning of 'Insan Kamil' in the concept of the tasawwuf philosophyal-wujud iin the concept of martabat nan tujuh.

The concept of martabat nan tujuh essentially discusses human events. Simuh (1995) states that martabat [nan] tujuh is the development of an understanding of divinity in tasawwuf which is inclined to be pantheisticmonistic. This concept states that everything that exists in the universe is an external aspect of a single divine essence, namely God. Regarding the creation of man, the framework of thought of martabat [nan] tujuh, in Wirid Hidayat Jati, is explained as follows:

...in the beginning I created (1) hayyu (life) with the meaning sajaratul yakin, which grew in the endless and timeless world of adam makdum; then (2) a light by the name of Nur Muhammad; then (3) a mirror by the name ofmiratul haya' $i$; (4) then a soul by the name ofruhidlafi; (5) then a lamp by the name of Kandil; (6) then a gem by the name ofdarrah; (7) then a cover by the name of hijab - the dignity of a perfect man (martabatinsankamil), that is what shrouds My presence (Simuh,1995: 217).

Thus, in the teaching about creation,the Divine Essence (Dzat Tuhan) is revealed (bertajjalli) to become seven dignities (tujuh martabat):sjaratul yakin, Nur Muhammad, miratul haya'i, ruh idlafi, Kandil, darrah, and hijab. The essence that forms the basic concept in this article is not the study of human creation by the Absolute Being or the seven dignities of the perfect man but rather the symbol or number 7 (seven) itself in a different kind of reality.

To the followers of tarekat Syattariyah in Minangkabau, the paradigm associated with the symbol or number 7 (seven) is part of the religious teachings to which they adhere, which includes the attributes known asma'ani, or the 7 (seven) characteristics of God that are found in human beings. In addition, it is commonplace for followers of tarekat Syattariyah to commemorate - or mystify - death days, such as manigo hari (commemorating the third day), manujuah hari (commemorating the seventh day), and maduo kali tujuah (commemorating the 'two times seventh' day - or the $14^{\text {th }}$ day), after a person's death.Other phenomena that are related to the concept of the number 7 (seven) are the use ofaia tujuah munsajik (water of seven mosques), kasiak tujuah muaro (sand from seven estuaries), banang tujuah ragam (seven kinds of yarn) and so on, which are used in "the specialized knowledge of shamanism".

Meanwhile, the aesthetics of the performance of indang also use the number 7 (seven) and multiples there of. The players (anak indang) consist of 7 (seven) people), performances last for 14 nights ( $2 \times 7)$, and are given by 21 indang groups, and are described by the people of Pariaman as tujuah kali naiak indang (seven times naik indang). In terms of its ontological dimension, this phenomenon is interesting to discuss when connected with 
the tasawwuf wujudyyah teaching institutionalized by tarekat Syattariyah in Minangkabau. The basis of the tasawwuf wujudyyah teaching is the religious doctrine which tasawwuf leaders call the knowledge of martabat nan tujuh".

\section{Literature Study}

The literature study for this research can be grouped into four domains, namely: the first domain, related to tasawwuf; the second domain, concerned with aesthetics; the third domain, related to the material object indang; and the fourth domain, supporting literature. Literature related to the theme of tasawwuf includes the work by Aboebakar Atjeh (1993: 23), which provides a basic explanation about the ontological aspect of the emergence of the terms Sufism and tasawwuf as a consequence of the lack of balance in people's lives between their sense of reason and their desires. Sufi teachings minimalize - obliterate - power, keeping it to the lowest level so that people can avoid greed in their lives through the Sufi path and its knowledge, known as tasawwuf. Hamka (1980: 157) highlights the doctrine of wujudyyah introduced by Syeik Burhanuddin throughtarekat Syattariyah in Pariaman, based on the knowledge ofmartabat nan tujuhwhich refers to the thoughts of Al-Halajj from Ibnu Arabi; it was welcomed and disseminated by Hamzah Fansuri in Aceh, and subsequently developed in Minangkabau through Syeikh Burhanuddin.

Simuh (1995: 217) discusses the concept of martabat nan tujuh; in essence it is the belief that everything that exists in the universe is an external aspect of a single divine essence, namely God. The goal of studying martabat nan tujuh through tasawwuf is to reach Dzat Al Haqq or the Divine Essence (God) and become one with Him.

There is an analogy which tells about the journey of a group of birds, led by a bird named Hut-hut, who are on the way to visit their king - Simurgh ("thirty birds" in Persian). Mojdeh Bayat (1997: 59) explains how on their spiritual journey, the birds pass through 7 (seven) valleys to meet and unite with their king. First is the valley of seeking; second the valley of love; third the valley of makrifat (supreme knowledge); fourth the valley of separation; fifth the valley of unity; sixth the valley of wonder; and seventh the valley of mortality and death.

On the other hand, from a methodological point of view, Abdul Qadir Djailani (1996: 195) describes the seven phases that are passed through to reach - [tarqy - ascend] - the Absolute Being in the study of tarekat. Djailani's logical analysis and explanation can be used as a reference and basic idea that the phenomenon of the number 7 (seven) is not only concerned with the study of tasawwuf but also enters into the realm of culture, such as in the organization or management of an indang performance in the Pariaman community. Another different case is the aspect of sharia, such as in the pillars of Hajj, in which the phenomenon of the number 7 (seven) and multiples thereof can also be found - for example in tawaf, sai, and stoning the jumrah. In addition, the same phenomenon also exits in shamanism.

An article for the proceedings of a seminar by Johari Matt (1999: 46) entitled "Tasauf Falsafi dan Wahdatul Wujud Menurut Islam" (Tasawwuf Philosophy and Wahdatul Wujud According to Islam") focusses on the problem of the philosophy of tasawwuf - how a human being can become Insanul Kamil (man of God). From one point of view, he is seen as human, from another point of view, as God. This is the meaning of 'insan kamil' in the tasawwuf philosophy al-wujudi in the concept of "martabat [nan] tujuh". The ideas of Johari Matt, Simuh, and Hamka have a similar understanding of the concept of martabat nan tujuh in relation to the problem of tasawwuf. However, the three of them do not discuss the synchronization of the phenomenon of the number 7 (seven) with other realities such as the pillars of Hajj, culture (art), and shamanism.

Meanwhile, reference to literature on the subject of aesthetics includes the works of Matius Ali (2011); Darsono (Soni Kartika - 2007); Martin Suryajaya (2016); and Kartini Pramono (2009). These four writers essentially focus only on the historical aspects surrounding the emergence of the term aesthetics. In further developments, Darsono and Martin Suryajaya begin to revise the understanding of aesthetics as something that is not only concerned with beauty but can also be understood as a sense of perception and the various feelings it arouses.

Literature that is related directly to the material object, whether articles or academic theses, includes works by Asril (Article, 1997: 45); Ediwar (Thesis, 1999: 182); and Nurmalena (Article, 2014: 250).In addition to explaining the term indang and the structure of its performance, Asril looks at indang from three perspectives, namely its music, literature, and dance. Ediwar discusses the emergence of three large indang groups (guguih) which represent the education system of the surau - Sufism. Nurmalena, meanwhile, attempts to explain indang from the dance perspective. Other supporting literature includes works by Taufik Abdullah (1987); Idrus H Alkaf (undated); Christine Dobbin (1992); Burhanuddin Daya (1995); and Fazlur Racham (1992).

\section{Research Method}

A qualitative method was chosen since it was considered relevant to the focus of the study. The researcher was the main instrument directly responsible for collecting data about the material object - indang in the Pariaman community. The collection of primary data was through participant observation, interviews, and documentation. 
The primary data obtained through these three models of investigation formed the basis for the analysis in accordance with the focus of the research. In addition, secondary data was also needed to strengthen the argumentation so that the research could achieve a level of credibility that could be accounted for scientifically.

Participant observation was the second step undertaken in the research, by observing a live performance of indang in Nagari Limau Puruik Pariaman, after the writer had read various literature - articles - related to indang in the Pariaman community. The information and empirical knowledge gathered through direct involvement in a performance was used to form guidelines for interviewing the informants. The data from the interviews with informants was grouped into four categories. The first was about indang performance in the surau and laga-laga. Indang performances in the surau contain material about the study of tarekat, such as the characteristics of God, known also as sifa 20, the origins of the universe and all it contains, and so on. Laga-laga is a special place made from bamboo slats that are tied together with rope, measuring around $6 \times 8$ meters.

Second, data related to the emergence of the concept indang tigo sandiang (three sides of indang) which represents the education system of the surau. Third, data about the management or organization of indang, including the number of anak indang - players - (7 people) in each group, with the following roles: 1 (one) tukang dikia (dhikr); 2 (two) tukang apik (tukangapit) - to the left and right; 2 (two) tukang pangga (tukang penggal); and 2 (two) tukang kalang (tukangpelang). Fourth, data related to the implementation of performances of indang tigo sandiang - alek ketek (small-scale ceremonies) and alekgadang (large-scale ceremonies). The organization of a performance is related to the emergence of the mystification of the symbol or number 7 (seven) and its multiples. It begins with the 7 (seven) anak indang who belong to three guguih indang; performances last for 14 nights - equal to $2 \times 7$; participants include 21 indang groups - equal to $3 \times 7$. Each guguih consists of 7 indang groups.

In addition to interviewing, audio-visual documentation was also obtained to complement the data and strengthen the argumentation that this event really exists and is in accordance with the context. The documentation was equally important to help the writer recreate a performance of indang tigo sandiang in accordance with the context, for the purposes of analysis. The analysis of the data was performed using an inductive method - in accordance with the phenomenological nature of the research, and the researcher constructed an emic thought pattern for providing the explanation. The writer did not depart from an a priori etic theory, because formal theories are not able to explain some of the phenomena - findings, or realities - that exist in an indang performance in the Pariaman community, which is the material object of the study.

\section{RESULT AND DISCUSSION}

The Dimension of Tasawwuf and Martabat Nan Tujuh

Referring back to the beginning of this article, tasawwuf can be described as Islamic mysticism or the mysticism that has developed in Islam. The main goal of a person who practices the teachings of tasawwuf, according to Abdul Hakim Hasan,in Simuh (1995), is to reach Dzat Al Haqq or the Divine Essence (God) and to become one with Him (Simuh 1995). In order to reach and enter the realm of the divine being, followers of Syattariyah wujudyyiah - use a formula of dhikr (reciting the phrasela Illaha Ilal lah). Al-Gazali in Simuh writes:

When it succeeds, the concentration of dhikr will lead to a state of fanain sensory awareness; beginning with kasaf, or pulling back the screen to reveal a deep understanding of the invisible realm, and reaching a climax with makrifat or supreme knowledge. The beginning of kasaf, for Sufis, is the start of mi'raj or ascension of the soul, enabling them to meet with angels and spirits of the prophets... Finally, this deep understanding of kasaf will allow them to meet God and even become one with God in a mystical union (Simuh,1995).

A mystical union is a mystical path which regards man as coming from God and is able to achieve a deep understanding of the re-union with God. In other words, a mystical union regards God as animmanent Beingor Essence (Dzat) who dwells in the universe and inside human beings. Those who believe in the mystical union emphasize a voluntaristic approach, or the endeavour to free oneself and dissolve one's own being in God, uniting one's own will with that of God (Simuh 1995).

Al-Gazali in Sumuh (1995) strongly rejects the school of thought that tends towards belief in the pantheistic immanenistic nature of the Divine Being since pantheism describes God as an immanent Being or Essence (Dzat) who also exists inside human beings, or hulul (the doctrine that believes God's spirit lives inside us), and hushul (the doctrine that believes in reaching God), and these beliefs are no more than a fantasy. In Minangkabau, this phenomenon can be found in the teachings oftarekat Syattariyah, Samaniyah, and Rifai'yah, and in some of their religious practices. In principle, religious practices that are directed towards reaching a union with the Creator can be seen in the teachings known as the study of sifat dua puluh (twenty characteristics).

Sifat dua puluh refers to the 20 characteristics or attributes of Allah that must be known. These twenty characteristics are: (1) wujud (existing); (2) qidam (before the before/eternal); (3) baqa (infinite); (4) mukhalfatu lilhawadis (different from the creatures He created); (5) qiyamuhu binafsihi(Allah stands alone); (6) wahdaniyah (singular/one); (7) qudrat (powerful); (8) iradat (having a will) (9) ilmun (knowing) (10) hayat (ever-living); (11) 
sama' (all-hearing); (12) basyirun (all-seeing); (13) kalam (speaking); (14) qadirun (most exalted) (15) muridun (free to choose); (16) 'alimun (all-knowing) (17) hayyun (alive); (18) sami'un (all-hearing); (19)basyiran(allseeing); (20) mutakalimun (all-speaking). These twenty characteristics are usually sung in a particular rhythm.

From this teaching, it is seen that there is a similarity between the 7 (seven) characteristics of God and the characteristics of man - which they refer to as ma'ani.Habibusman Bin Yahya (1996) states that the forms of instruction that are related to tasawwuf are those that study the twenty characteristics. One of the topics associated with the method of 7 (seven) is the characteristics ofma'ani, or the 7 (seven) characteristics of God that are also possessed by human beings, namely: (1) sami'un (hearing); (2) basyar (seeing); (3) qudrat (power); (4) iradat (having a will); (5) ilmun (knowing); (6) hayat (living); and (7) kalam (speaking). The comparison of these 7 (seven) characteristics of God with the 7 (seven) characteristics of man (as His creation) is what led to the concept Insanul Kamil(a person who has reached perfection) being Al-insanul-illahi (a man of God), described byJohari Mat, as explained in the previous section.

The above conception cannot of course be separated from the influence of well-known Sufi leaders, such as Al-Hallaj, who pledged that "I am the truth" (anaal-Haqq). According to Mojdeh Bayat (1997), he became famous for saying "I am the truth" and this is what led to his brutal execution. To orthodox religious leaders, his death was justified with the reason of bida'ah, because eksoteric Islam cannot accept the viewpoint that a person can be united with Allah - and the Truth (al-Haqq) is another name by which Allah is known; therefore, AlHallaj was stating his own Godliness. Compare this with Firaun in his statement "I am God". The thoughts (teachings) of al-Hallaj can be read through the poetry he wrote: the problem remains his statement about uniting with God. This series of poems are quoted in Hamka'swriting, which reads as follows:

Your spirit has merged with my spirit

Like mixing wine with clear water

If something touches You, I too am touched

Therefore, You are me in all things

And there is nothing inside my robes other than Allah (Hamka, 1980).

From the quotation above, it is clear that the thoughts or teachings of al-Hallaj have touched on the realm of the Divine Being; he even states directly that he is God. Al-Hallaj's teachings were also followed by other Sufi leaders such as Abu Yazid, who in a statement presented in an article by Aboebakar Atjeh, says as follows:

There is no other God except me, worship me, I am so pure. How great is my power. And he also says: Allah once lifted me up and placed me in front of Him. Then He spoke to me: O, Abu Yazid,

My creatures wish to see you. Then I beseeched: adorn me with Your wahdaniat, clothe me in Your own clothes, lift me up to become one with You (Atjeh, 1989).

The words uttered by Abu Yazid above imply his own self-acclamation as God. This acclamation is based on the existence of the similarities between the 7 (seven) characteristics of God and the 7 (seven) characteristics of man. The comparison of the characteristics of God with those of man - known as ma'ani - isontologically based on the knowledge of martabat nan tujuh, which subsequently gave rise to the concept Insanul Kamil (the perfect man isal-insanul-illahi - aman of God).From the point of view of Islamic law or Sharia, it can be said that God, as the Divine Essence (Dzat) who created the universe (including man), cannot be compared with or equated to the essence or matter (zat) that He created. Islam teaches that everything that exists is made up of two essences: God and the universe, the Creator and the creatures He created. The fundamental difference between God and the universe, both in terms of essence and existence, is extremely important. This basic different is stated in the al-Qur'an: ...there is nothing at all like Him and He is the One who hears and sees allthings (asySyura; 11).

This warning by God, written in the al-Qur'an in sura asy-Syura ayat 11 makes it clear that God cannot be equatedwith or compared to the universe, which includes human beings, or anything He created. The thought concept which compares the characteristics of God with those of man appears in the teachings of wujudyyahwhich are institutionalized intarekat Syattariyah.

The wujudyyah doctrine introduced by Syeikh Burhanuddin through tarekat Syattariyah in Pariaman is based on the knowledge of martabat nan tujuh. Hamka writes as follows:

According to the knowledge of martabat nan tujuh, in practicing suluk a person must perform tawajjuh (come before Allah using arabithah, or a sheikh or caliph to act as an intermediary. After passing through the door of tawajjuhorrabithah, the person will reach a state of fana. From the state of fana, he will then proceed towards baqaa until he reach esla anna illa hu (there is no longer me, only Him)...The doctrine of wihdat'ul wujudis the doctrine of Al-Halajj from Ibnu Arabi which was accepted and propagated by Hamzah Fansuri in Aceh in the $17^{\text {th }}$ century, and this is what has developed in Minangkabau, especially in Pariaman. The meaning of this doctrine is that the universe is simply the manifestation (Mazhar) of Allah and everything is one, la Illaha Ilal lah - there is no other God but Allah (Hamka 1984).

Methodologically, Abdul Qadir Djailani (1996) states that the seven phases of ascending - tarqy - to reach 
the Absolute Being in the activity of recitation and study are explained as follows: (1) having conviction; (2) repenting; (3) mujjahadah (undergoing a test or struggle); (4) reaching a state of spiritual ecstasy; (5) muksyafah (revelation or pulling back the screen); (6) having a vision (musyaadah), in which the spirit is in a dreamlike state; and (7) fana (dissolving) to become one in form with Allah. The concept described above is still found in centers for religious study belonging totarekat Syattariyah,such as in the Ulakan prayer house orsurauin Pariaman. At this point, Idrus H. Alkaf gives a signal that ...every seven cases withseven other cases is a notice to people with knowledge; that the number 7 (seven) contains a great secret and holds an important place at the side of Allah (Alkaf, undated; xi).

From the perspective of shariat, the thoughts of Idrus H. Alkaf are correct. This can be seen from the implementation of the Hajj, especially the stages associated with: (1) tawaf; (2) sya ' $i$; and (3) throwing thejumrah. Tawaf (circling the Kaaba) 7 (seven) times; sya' $i$ (running between the hills of Syafa and Marwa), and throwing the jumrah with 7 (seven) stones and in three places - making a total of 21 stones. This is what Idrus H. Alkaf means when he says that ... every seven cases with seven other cases is a notice to people with knowledge. The implementation of the various stages of the Hajj has a historical value - the facts are as seen, with no explanation from Allah SWT, especially in connection with the question of why it must be the number 7 (seven). This is a part of faith or conviction that should be accepted without question.

\section{Aesthetics of Indang Pariaman}

The word aesthetics comes from the Greek word aisthetika which means things that are absorbed by the senses. For this reason, aesthetics is often understood to mean a sense of perception and the variety of feelings it arouses (Ali 2011; Pramono, 2009; Suryajaya, 2016). Dharsono states that aesthetics is no longer merely a philosophical issue since it is also concerned with the scientific or scholarly discussion of a work of art (Dharsono, 2007). Aesthetics is the study of art as an object of beauty - which beings pleasure - that can be observed by the senses in all its complexity - in this case referring to indang Pariaman.

The complexity of indang as a product of behaviour is related to the norms - or values - adhered to by the Pariaman community. These norms and values were formed based on the religious principles or belief in practicing the method of tasawwuf. From this phenomenon we can identify the complexity of indang as an aesthetical entity. This aesthetical entity is made up of several components, namely: (1) the indang players (anak indang); (2) the reciter of dhikr or caliph (tukang dikia or kulipah); and (3) the management of performances.

1. Anak Indang

The anak indang consist of at least7 (seven) players; one person acts as the central figure and is known as the tukang aliah. To the left and right of the tukang aliah are 6 (six) more players who are referred to as the tukang apik, tukang pangga, andtukang palang - two of each kind - so together with the tukang aliah there are 7 (seven) players in total. The tukang palang may consist of more people, up to a total of around 21 , as shown in the diagram below.

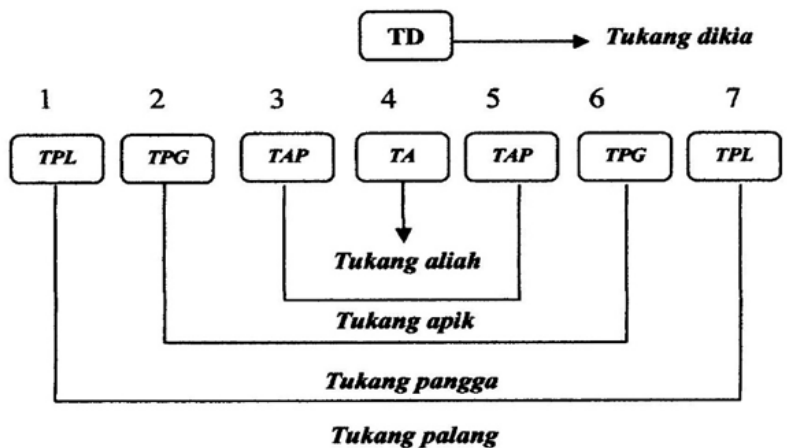

Diagram 1. Structure of anak indang players and tukang dikia (Andar, 2017)

The diagram above shows that the anak indang consist of 7 (seven) players, one of whom holds the position of tukang aliah. Ediwar states that the tukang aliah-also sometimes known as thetukang karang - is the main assistant of the tukang dikia in creating the story. In addition, he has the task of beginning and ending the performance, determining the rhythmic patterns of the rapa' $i$ and dance movements, and transitioning from one melody to another. The tukang aliah's position is in the center of the anak indang players who sit in a row (Ediwar 1999). The position of the tukang aliah in a performance of indang can be compared to that of a religious leader or teacher who is emulated in the prayer meetings or study sessions held by the tarekat groups. The seven anak indang are synonymous with the characteristics of ma'ani, or the comparison between the 7 (seven) characteristics of God and the 7 (seven) characteristics of man -and also with the concept of knowledge of martabat nan tujuh as mentioned in the previous section. In this case, it can be said that art, in its various forms, should be synchronized with the life values adhered to by the community in which it exists.Hajizar 
emphasizes that art in its various forms must be synchronized with - or represent - the life values upheld by its supporting community (Hajizar, interview, 2017).

The tukang apik are the two players who sit to the left and right of the tukang aliah in an indang performance. One of them has the role of providing variations (meningkah) on the sound of the rapa'i played by the tukang aliah. The other one's role is to play different patterns on the rapa' $i$ from the first tukang apik. The tukang panggaare the two players who sit to the left and right of thetukang apik. Their role is to follow the rhythms of the rapa' $i$ played by the second tukang apik. The tukang palang are the two (or more) players who sit at each end of the row, or to the left and right of the tukang pangga. They play the same rhythmic patterns as the second tukang apik.

\section{Tukang Dikia}

The tukang dikia is the main figure in an indang performance. He sits behind the tukang aliah and presents the text (rundingan); in the second verse, the anak indang join in with the singing of the tukang dikia. In the past, the tukang dikia presented texts related to the twenty characteristics or sifat duapuluh and the story of the prophet Muhammad saw etc. Recitation of the twenty characteristics usually takes place in prayer houses belonging to the Syattariyah community.

Performances of indang in Pariaman are held for various forms of traditional village ceremonies, or alek nagari, known as alek ketek (small-scale ceremonies) and alek gadang (large-scale ceremonies). Asril (2007) states that analek ketekconsists of 3 (three) times "naiak indang". Three times naiak indang is equal to 6 (six) nights of performances given by 9 indang groups.

Alek gadang effectively takes place for 14 days, or 7 (seven) times naiak indang. Hence, the number of indang groups performing is 21 groups $(7 \times 3$ groups $=21$ groups). These 21 indang groups are divided into three main groups of 7 (seven) - namely 7 (seven) groups acting as the host (sapangka), 7 (seven) groups as alek duo (close guests), and 7 (seven) groups as alek satu (distant guests) (Ediwar, 1999:181). In terms of its ontological dimension, this kind of form of performance is founded on the teachings of tasawwuf; this was verified by Asril - an observer of the indang art form - who states that the number of indang players is 7 (seven) and the number of groups is 21 - which is the same as $7 \times 3$ - and performances take place over a period of 14 nights - or 7 x 2, consistent with the teachings of tasawwuf (Asril, 2017).

In order to arrange a performance of indang, it is necessary to make very careful calculations with regard to the indang sapangka, alek duo and also alek satu. The sapangka is the indang group that comes from the village (nagari) where the indang performance is taking place. In the context of an indang performance for a small-scale ceremony or alek ketek, the sapangka is a single indang group. In a large-scale ceremony, or alek gadang, however, the sapangka consists of 7 (seven) indang groups. Therefore, for the implementation of an alek gadang performance, 6 (six) more indang groups are required to play the role of the sapangka.

These six additional groups come from neighboring villages and have a special bond with the sapangka group (the group hosting the event) - a bond which they refer to as sa guguih (belonging to the same group). In the context of indang groups, sa guguih means belonging to the same school of thought - even though they come from a different village. In administrative terms, a nagari - which outside West Sumatera is called a village - is the smallest or lowest level of a government unit in West Sumatera.At the present time, there are 3 (three) guguih indang in the Pariaman community, namely: (1) guguih Tankarin; (2) guguih Amir Unggun; and (3) guguih Maruik. The word which follows the word guguih is the name of the person (teacher) the group follows. Therefore, it can be said that even though an indang group comes from a different village, it may act as the sapangka in a ceremony, on condition that it belongs to the same guguih. Ediwar (1999) explains this as follows: ...an indang group in another village (nagari) may become a sapangka. This group may not be selected at random but must have a close bond with the sapangka group (the host), a bond referred to as guguih... Indang groups that belong to the same guguih have a very strong emotional bond, even though they may come from a place far away.

The description of guguih above, as a form of emotional bondorbrotherhood, shows that the fraternal bond between different indang groups is exactly like the spiritual genealogy - ranji- in the organization of tarekat Syattariyah. The spiritual genealogy of this tarekat is always connected with the time when the sheikh (teacher of the tarekat) founded a particular prayer house far from the main center of the tarekat.

The spiritual genealogy described above has important meaning in the prayer and study meetings of tasawwuf, in association with Allah SWT. In order to form a relationship with Allah SWT, it is necessary to use a tasawwuf teacher or sheikh as an intermediary. According to the beliefs of followers of tasawwuf teachings, a person must pass through the door of tawajjuh or the medium of a teacher. In other words, the position of a teacher in the practice of tasawwuf is highly revered. For this reason, it is not surprising that in tarekat centers, the picture of the teacher (sheikh) is always placed in a position where it can be seen by the members of the tarekat.

Another interesting phenomenon in the Pariaman community is that a person known asAngku Saliah Kiramaik (The Holy One) has an important status in the hearts of the local people, especially those who are 
oriented towards tarekat Syattariyah. Wherever the Pariaman people may go to settle, they always bring the picture of Angku Saliah Kiramaik with them to hang on the walls of their restaurants or the places where they do business. Angku Saliah Kiramaik has a significant value for the people of Pariaman, and the person referred to asAngku Saliah Kiramaik has a great influence on the way the Pariaman people live their lives.

\section{Management of Indang Performances}

The management of indang performancesrefers to the organization of the participants in indang groups that are found in various districts of Pariaman. Ediwar (1999) states that after 7 (seven) groups have been determined as the sapangka for a performance, the number of alek groups chosen is 14, consisting of 7 (seven) groups for the alek duo (close guests) - as the supadan, and 7 (seven) groups for the alek satu (distant guests). Based on the way in which indang groups are chosen to participatein an alek gadang, it can be seen that the number 7 (seven) is always the basis for organizing and determining which indang groups will take part in the alek nagari. This of course pays attention to the fact that the groups should belong to different guguih.

Asril (2017) states that the arrangement of indang groups that are going to participate in analek gadangcan be divided into four stages, namely: (1) indang jolong (beginning); (2) indang lambuang (second); (3) indang panggalang (penultimate); and (4) indang panutuik (closing).

Indang jolong (the beginning) is the first sapanaiak performance (one packet) of 7 (seven). The performance of an alek gadang begins with the indang sapangka group which is hosting the event, not one of the indang groups that are acting as or representing the sapangka. The performance continues with the alek duo and alek satu. The indang lambuang performance starts after the indang jolong has finished. The indang lambuang includes 4 (four) performances (naiak indang), from the second to the fifth of the 7 (seven) performances (naiak indang) in the alek gadang. The indang panggalang performance is the penultimate performance or the performance before the indang panutuik in an alek gadang ceremony. The indang panutuik is the final sapanaiak indang performance and the climax of the entire indang performance in an alek gadang ceremony (Ediwar, 1999).

It should be mentioned that a singles apaniak indang takes place over2 (two) successive nights. This means that the indang sapangka, alek duo and alek satu groups each perform twice. Thus, seven sapanaiak indang means 14 nights of performance. In connection with the management of indang Pariaman performances in alek gadang, it can be concluded that the number 7 (seven) is the basis for determining the number of sapangka, alek dua, andalek satu groups - a total of 21 groups. The same is true for performances which take place over a period of 14 nights, which is the same as 2 (two) times 7 (seven). This can be seen more clearly in the diagram below.

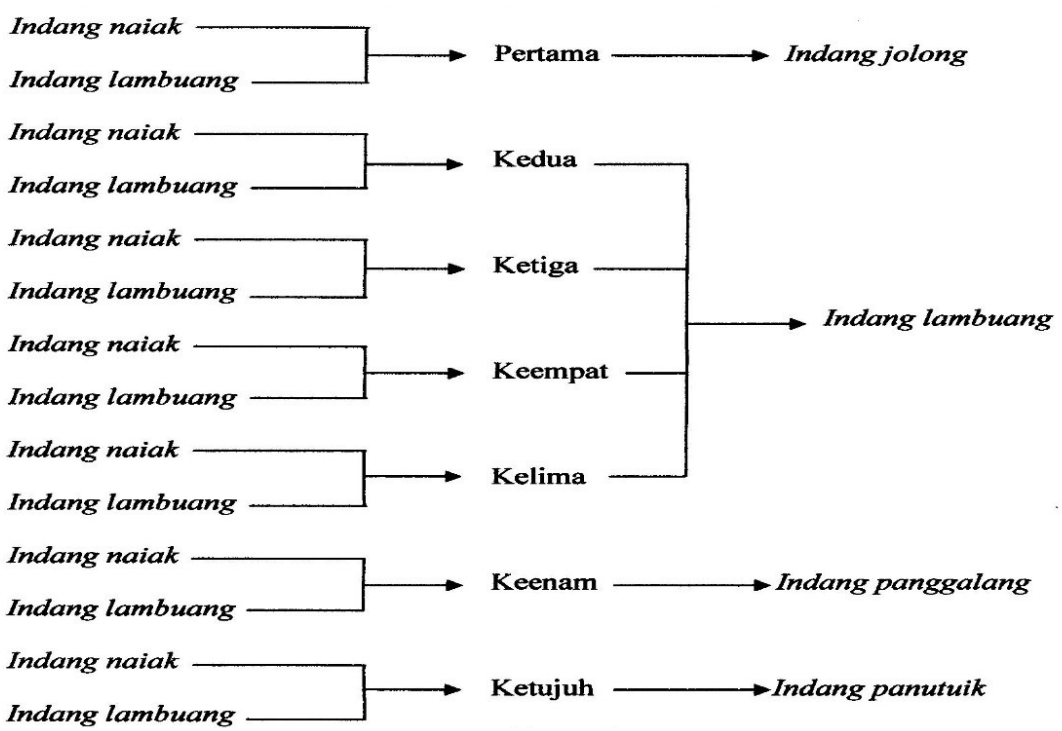

Diagram 2. Structure of indang Pariaman performance in alek gadang (Source: Ediwar, 1999)

The diagram above shows the scheme or diagram for the competition of indang performance in an alek gadang ceremony in Pariaman, arranged according to the concept of indang naiak and indang lambuang for each night of the performance. Based on the concept of indang naiak andindang lambuang, the performance is divided into 4 (four) sections, namely theindang jolong, indang lambuang, indang panggalang, andindang panutuik. According to these conditions, it can be said that the management of indang Pariaman performances, from an ontological dimension, is based on the tasawwuf idea of wujudyyah. This idea can be seen in that the management of performances is based on the number 7 (seven) which is used for determining the sapangka, alek $d u o$, andalek satu groups.(In addition to this, the implementation of the entire performance is also calculated as 2 $\mathrm{x} 7$ (seven) which is equal to 14 nights. 


\section{CONCLUSION}

One of the most basic aspects of the tasawwuf dimension of wujudyyah is tarqy (ascending levels), which is referred to as tawajjud (religious devotion). Tawajjud is described as the endeavor to become completely absorbed in a state of religious devotion in order to find, achieve, or reach Dzat Al Haqq or the Divine Essence (God) and become one with Him. The foundation of the spiritual knowledge of tarqy which leads to tawajjud is based on the knowledge of martabat nan tujuh. This is a method of ascending by level - through seven stages to enter the realm of the Divine Being in a state of joy (wajd), with the help of an external stimulus which usually uses a formula of dhikr.

The religious practice which leads to a union with the Creator can be seen in the recitation of the twenty characteristics (pengajian sifat dua puluh). In this doctrine, there are found to be similarities between the 7 (seven) characteristics of God and the characteristics of man - which are referred to as characteristics of ma'ani. These characteristics are recited or sung together by followers of the tarekat under the guidance of a sheikh. The transformation of the twenty characteristics, based on the knowledge of martabat nan tujuh, "becomes" and "is" a different reality in the aesthetical manifestation of the performance of indang Pariaman.

The aesthetics of an indang Pariaman performance are created by several elements, namely: the anak indang, tukang dikia or kulipah, and management of performances. These three elements reflect the transformation of spirituality in a different function and form. The number 7 (seven) in the dimension of tasawwuf is the levels in the ascending path (tarqy), known as tawajjud (religious devotion), to reach the realm of the Divine Being. The number 7 (seven) in the aesthetics of an indang Pariaman performance is a unique characteristic which indicates that this art originates from the dimension of thought of tasawwuf.

\section{References}

Abdullah, Taufik. (1987). Adat dan Islam, Suatu Tinjauan Tentang Konflik di Minangkabau in Taufik Abdullah (ed.), Sejarah dan Masyarakat Lintasan Historis Islam Indonesia. Jakarta: Pustaka Firdaus.

Atjeh, Aboebakar. (1989). Pengantar sejarah Sufi dan Tasauf. Solo: Ramdani.

Ali, Matius. (2011). Estetika Pengantar Filsafat Seni, Yogyakarta: Sanggar Luxor.

Alkaf, Idrus H. (n.d.)Mengungkap Tujuh Rahasia Gaib. Surabaya: Karya Utama.

Bayat, Mojdeh/ (1997). Negeri Sufi; Kisah-kisah Terbaik. Jakarta:Lentera Basritama.

Darsono (Soni Kartika). (2007). Estetika. Bandung: Rekayasa Sain.

Daya, Burhanuddin. (1995). Gerakan Pembaharuan Pemikiran Islam: Kasus Sumatera Tawalib. Yogyakarta: PT.

Tiara Wacana.

Djailani, Abdul Qadir. (1996). Koreksi Terhadap Ajaran tasauf. Jakarta: Gema Insani Pers.

Dobbin, Christine. (1992).Kebangkitan Islam Dalam Ekonomi Petani Yang Sedang Berubah. Jakarta: Innis.

Ediwar. (1999). "Perjalanan Kesenian Indang Dari Surau Ke Seni Pertunjukan Rakyat Minangkabau Di Padang Pariaman, Sumatera Barat”. Tesis. Yogyakarta: Universitas Gadjah Mada.

Hamka. (1980). Tasauf Perkembangan dan Pemurniannya. Jakarta: Nurul Islam.

Mat, Johari. (1999). Tasauf Falsafi dan Wahdatul Wujud Menurut Islam. Prosiding Seminar. Kuala Lumpur: Badan Perhikmatan Penerangan Islam Selangor dan Wilayah Persekutuan (BPPI).

Mat, Johari. (1999). Tasauf falsafi dan wahdatul wujud menurut Islam, Prosiding Seminar. Kuala Lumpur: Badan Perhikmatan Penerangan Islam Selangor dan Wilayah Persekutuan (BPPI), tahun 1997.

Nurmalena \& Rustiyanti. (2014). Kesenian Indang: Kontinuitas dan Perubahan. Panggung: Jurnal Ilmiah Seni \& Budaya. Volume 21 Number 3. September 2014: 250-257.

Simuh. (1995).Sufisme Jawa. Yogyakarta: Yayasan Bentang Budaya.

Suryajaya, Martin. (2016). Sejarah Estetika. Jakarta: Gang Kabel.

Yahya, Al-Habib Usman bin Abdullah bin. (1996). Awaludin Sifat Duapuluh. Jakarta: S.A. Alaydrus.

Pramono, Kartini. (2009). Horizon Estetika. Yogyakarta: Kahfi Offset Fakultas Filsafat Universitas Gadjah Mada.

Rachman, Fazlur. (1992). Islam. Jakarta: PT. Bumi Aksara. 